\title{
Simulated effects of climate change, fragmentation, and inter-specific competition on tree species migration in northern Wisconsin, USA
}

\author{
Robert M. Scheller ${ }^{1,2, *}$, David J. Mladenoff ${ }^{1}$ \\ ${ }^{1}$ Department of Forest and Wildlife Ecology, University of Wisconsin-Madison, 1630 Linden Drive, Madison, \\ Wisconsin 53706, USA \\ ${ }^{2}$ Present address: Conservation Biology Institute, 136 SW Washington, Suite 202, Corvallis, Oregon 97333, USA
}

\begin{abstract}
The reproductive success, growth, and mortality rates of tree species in the northern United States will be differentially affected by projected climate change over the next century. As a consequence, the spatial distributions of tree species will expand or contract at differential rates. In addition, human fragmentation of the landscape may limit effective seed dispersal, and inter-specific competition may limit the migration of climate-adapted species, restraining the rate of tree species migration. If the northward migration of tree species adapted to a warmer climate lags behind the rate of climatic change, overall growth rates and aboveground biomass of northern forests may be significantly reduced relative to their potential. We used a spatially interactive forest landscape model, LANDIS-II, that simulates tree species establishment, growth, mortality, succession, and disturbance. We simulated multiple scenarios of disturbance and climatic change across a $\sim 15000 \mathrm{~km}^{2}$ forested landscape in northwestern Wisconsin, USA. These simulations were used to estimate changes in aboveground live biomass and the spatial distribution of 22 tree species. We observed a reduction in aboveground live biomass relative to the potential biomass for the combined soils and changing climate. We regressed the reduction of potential aboveground biomass against a measure of fragmentation, the initial biomass for 22 tree species, and soil water holding capacity calculated at 3 spatial resolutions. We also regressed the range expansion of 3 individual tree species that are expected to expand their distributions against the same variables. Species migration and range expansion were negatively correlated with fragmentation both in total and for 2 of the 3 species examined in detail. The initial abundances of some tree species were also significant predictors of species migration and range expansion and indicate significant competition between existing species assemblages and more southerly species that are expected to migrate north. In conclusion, the aboveground biomass of northern forests may be limited by interactions among climate change, interspecific competition, and fragmentation.
\end{abstract}

KEY WORDS: Climate change - Forest fragmentation - Interspecific competition · Carbon storage · LANDIS-II · Tree species range expansion · Tree species migration

\section{INTRODUCTION}

During Holocene climate change following the last glaciation, tree species dispersed to their current spatial distribution in eastern North America (Davis 1989, Mclachlan et al. 2005). The rapid rate at which some tree species reached their current distributions has been attributed to outlier populations near the Laurentian ice sheet (Mclachlan et al. 2005) and the continuity of the landscape (Iverson et al. 2004a). Projections of future migration rates indicate that there may be significant migration lags as the range expansion of tree species will not keep pace with the rate of climate change (Davis 1989, Malcolm et al. 2002, Iverson et al. 2004b). 
In addition to climatic and edaphic limitations, available habitat may be reduced by forest fragmentation. Forest fragmentation may significantly reduce the amount and spatial proximity of available habitat and therefore limit effective seed dispersal and successful establishment (Iverson et al. 1999, Collingham \& Huntley 2000) and may cause a reduction in species richness if the climate changes (Currie 2001, Iverson \& Prasad 2001). A significant portion of seeds produced may land in unsuitable habitat (e.g. cropland, urban areas, water). Furthermore, fragmentation reduces the density of mature, reproducing individuals that can disperse seeds and contribute to range expansion (Iverson et al. 2004b). Research suggests that seed source strength (the number or density of mature trees that can seed into a given location), not maximum seed dispersal distance, may be the largest limitation to tree species migration (Iverson et al. 2004b).

Tree species range expansion may also be inhibited by competition from the species that initially occupy a forested area (Malanson \& Cairns 1997). If a site is currently occupied by species that will significantly compete with migrating species, species migration and range expansion may be inhibited (Davis 1989, Malanson \& Cairns 1997). Such competition would be particularly important if existing species respond favorably to climate change. Competitive exclusion may also occur among migrating tree species. These interactions within existing forests and the ability of more southerly tree species to colonize new habitat may be particularly important if large, sudden 'die-offs' of the existing dominant trees do not occur (Davis 1989, Loehle \& LeBlanc 1996).

Finally, disturbance can also affect range expansion by moderating or enhancing the effects of fragmentation and competition. If a disturbance removes mature trees, it will reduce the source strength for that species. Alternatively, disturbance may remove or reduce species that currently occupy a site, reducing competition and enabling new species to become established and potentially expand their ranges. Disturbances are also required for the establishment of species with low shade tolerance.

Due to these multiple interacting factors, the gap between tree species' fundamental and realized niches may grow as a consequence of climate change and the inability of species to migrate in sync with climate change. If the migration rate of species lags behind the rate of climate change, both forest productivity and aboveground live biomass may be reduced relative to their climatic potentials (Scheller \& Mladenoff 2005). Tree species richness may also decline (Scheller \& Mladenoff 2005), and aboveground live biomass may be further reduced if one or more dominant tree species are locally extirpated before dispersal processes can provide functional replacements (Loehle 2000b, Scheller \& Mladenoff 2005). Although the individual effects of fragmentation, competition, and disturbance have been hypothesized or simulated, to our knowledge, no one has examined the combined effects of these multiple interacting factors.

We examined the consequences of migration limitations induced by fragmentation, competition, and disturbance across a landscape in northern Wisconsin, USA. This landscape has a broad gradation of fragmentation, diverse soils, contains tree species of varying climatic, shade, and disturbance tolerances, and is expected to experience rapid climate change. Some formerly dominant tree species would be expected to re-colonize habitat occupied before extensive logging in the late 19th and early 20th centuries if not otherwise impeded. Other tree species are currently located at the northern edge of their distribution within this landscape and would otherwise be expected to quickly expand their distributions northward. Yet other species would be expected to decline or be extirpated as the climate changes. Therefore, this landscape is ideally suited to examining a range of processes and interactions that are broadly applicable to northern temperate forests.

Within the context of this landscape, we specifically sought to examine (1) the effects of forest fragmentation on species migration and range expansion and (2) the effects of existing tree species abundances and distributions on species migration and range expansion. Furthermore, we hypothesized that competitive limits to migration would be largest where forests are currently dominated by species that will likely respond positively (increased growth rates and ability to establish) to climate change.

We assessed the consequences of climate change, fragmentation, competition, and disturbance as changes in potential aboveground live biomass $\left(B_{\mathrm{AL}}\right)$. Our estimates of $B_{\mathrm{AL}}$ were derived from a forest landscape simulation model, LANDIS-II, that simulates the spatial dynamics of forest succession, disturbance, seed dispersal, competition, and growth across large landscapes or regions (Scheller et al. 2007). We assessed total $B_{\mathrm{AL}}$ (all species combined) and the $B_{\mathrm{AL}}$ values for 3 species expected to significantly expand their current distributions over the next $200 \mathrm{yr}$.

\section{METHODS}

\subsection{Study area}

Our study area is located in northwestern Wisconsin (Fig. 1) and covers approximately 1.5 million ha. The climate is continental, with mild summers and cold 

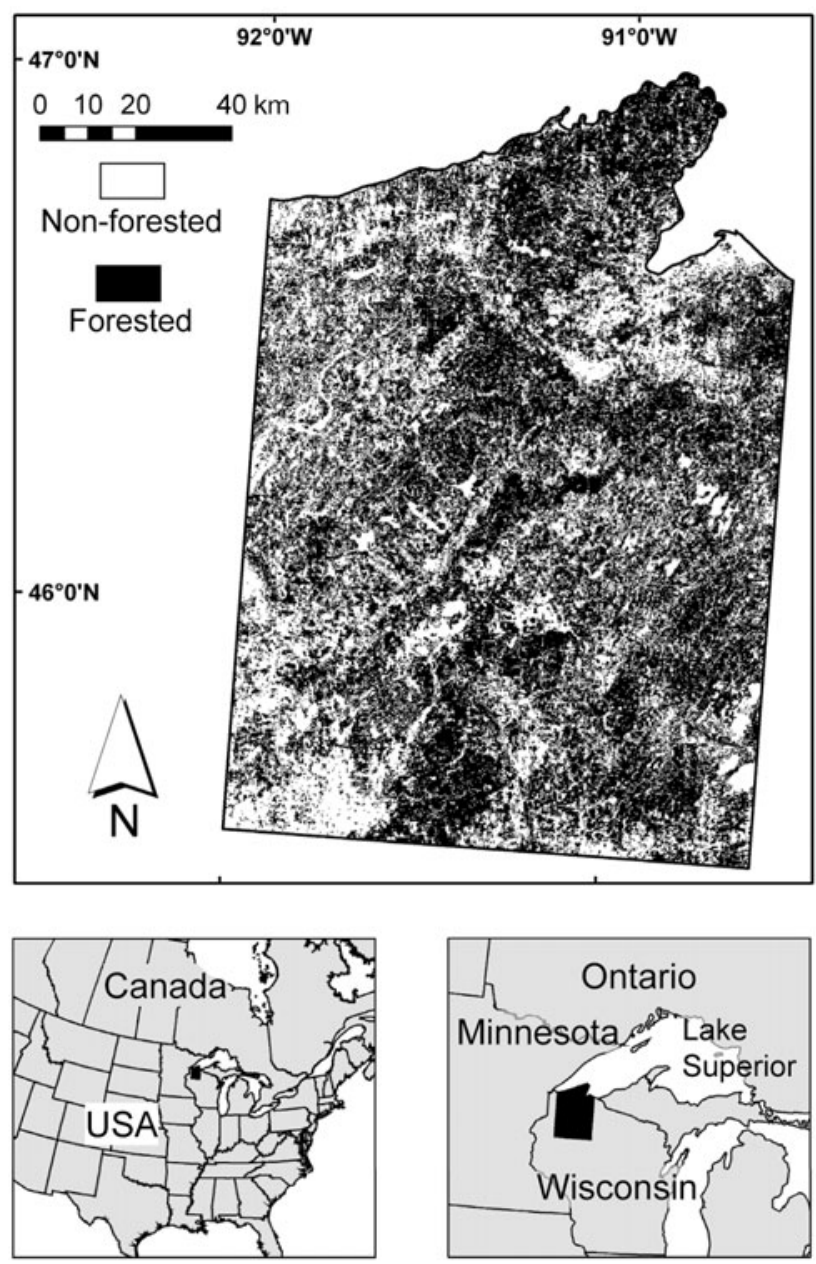

Fig. 1. Study area in northwestern Wisconsin, USA

winters. Precipitation is greatest during the summer months, with an annual average of $\sim 90 \mathrm{~cm}$. Soils vary considerably, from sandy outwash plains, to a clayrich former glacial lake bed, and silty or loamy uplands of glacial till (STATSGO 1994). The area was heavily logged in the late 19th and early 20th centuries, and most forests are second and third growth. Additionally, there are significant non-forested areas (lakes, wetlands, and agriculture) that create a landscape matrix with varying degrees of forest fragmentation (Fig. 1).

The area is dominated by mesic forests, with red maple Acer rubrum, sugar maple A. saccharum, yellow birch Betula alleghaniensis, bitternut hickory Carya cordiformis, white ash Fraxinus americana, black cherry Prunus serotina, red oak Quercus rubra, eastern white cedar Thuja occidentalis, basswood Tilia americana, and eastern hemlock Tsuga canadensis; drier pine and oak forests, with white oak Q. alba, northern pin oak $Q$. ellipsoidalis, bur oak $Q$. macro- carpa, black oak Q. velutina, jack pine Pinus banksiana, red pine $P$. resinosa, and white pine P. strobus; early successional big-toothed aspen Populus grandidentata, trembling aspen $P$. tremuloides, and paper birch B. papyrifera forests; and spruce-fir forests typical of southern boreal forests with balsam fir Abies balsamea, white spruce Picea glauca, paper birch, jack pine, and red pine (He et al. 1998). The spatial distribution of each species is dependent upon climate, soils, local disturbance regimes, and the legacies of human activities (Curtis 1959). We divided the dominant tree species into 3 climate categories, based on their current distribution relative to our study area: northern species (near the southern edge of their continental distribution), southern species (near the northern edge of their continental distribution and found only in the southern half of our study area), and 'climate-neutral' species with continental distributions centered near our study area or found distributed throughout our study area (Table 1).

Table 1. Input data for 22 species typical of northern Wiscon$\sin$ (USA) upland forests. Species are grouped by their climate tolerance, estimated by their current distributions relative to northern Wisconsin. 'Shade tolerance' is an index of the ability of species to establish under varying light levels whereby 1 is the least shade tolerant and 5 is the most shade tolerant (Scheller \& Mladenoff 2004). 'Effective ' and 'maximum' seeding distances represent the 95 and $5 \%$ probabilities of dispersal, respectively

\begin{tabular}{|c|c|c|c|}
\hline \multirow{2}{*}{$\begin{array}{l}\text { Distribution and } \\
\text { taxon }\end{array}$} & \multirow{2}{*}{$\begin{array}{l}\text { Shade } \\
\text { tolerance }\end{array}$} & \multicolumn{2}{|c|}{ Seeding distance $(\mathrm{m})$} \\
\hline & & Effective & Maximum \\
\hline \multicolumn{4}{|l|}{ Northern species } \\
\hline Abies balsamea & 5 & 30 & 160 \\
\hline Betula papyrifera & 2 & 200 & 5000 \\
\hline Picea glauca & 3 & 30 & 200 \\
\hline Pinus banksiana & 1 & 30 & 100 \\
\hline Pinus resinosa & 2 & 12 & 275 \\
\hline Thuja occidentalis & 2 & 45 & 60 \\
\hline \multicolumn{4}{|l|}{ Climate-neutral species } \\
\hline Acer saccharum & 5 & 100 & 200 \\
\hline Betula alleghaniensis & 4 & 100 & 400 \\
\hline Pinus strobus & 3 & 100 & 250 \\
\hline Populus grandidentata & 1 & 500 & 5000 \\
\hline Populus tremuloides & 1 & 500 & 5000 \\
\hline Quercus ellipsoidalis & 2 & 30 & 3000 \\
\hline Quercus macrocarpa & 2 & 30 & 3000 \\
\hline Quercus rubra & 3 & 30 & 3000 \\
\hline Tilia americana & 4 & 30 & 200 \\
\hline Tsuga canadensis & 5 & 30 & 100 \\
\hline \multicolumn{4}{|l|}{ Southern species } \\
\hline Acer rubrum & 3 & 100 & 200 \\
\hline Carya cordiformis & 4 & 150 & 3000 \\
\hline Fraxinus americana & 4 & 70 & 140 \\
\hline Prunus serotina & 3 & 30 & 3000 \\
\hline Quercus alba & 3 & 30 & 3000 \\
\hline Quercus velutina & 2 & 30 & 3000 \\
\hline
\end{tabular}




\subsection{Simulation model}

We used LANDIS-II, a spatially dynamic forest landscape model that simulates succession, disturbance, and seed dispersal (Scheller et al. 2007) and is derived from LANDIS (Mladenoff 2004). The inclusion of unique species attributes, temporally dynamic ecosystem processes (e.g. growth and decomposition), spatially explicit disturbances, and spatially dynamic dispersal enabled us to conduct the necessary analyses to address our objectives. Moreover, LANDIS-II was specifically designed for modeling regional scale landscapes undergoing climate change (Scheller \& Mladenoff 2005, Xu et al. 2007). LANDIS, LANDIS-II, and other LANDIS-derived models have been extensively tested and applied throughout the United States and the world (Mladenoff 2004). Application and sensitivity testing has been conducted for succession, seed dispersal, and harvesting extensions (Gustafson et al. 2000, Scheller \& Mladenoff 2004, Ward et al. 2005).

LANDIS-II operates on a landscape represented as a grid of individual cells, each with a separate suite of tree species. The grid cells are aggregated into ecoregions assumed to have homogeneous conditions (e.g. climate and soils) for tree species growth, establishment, and coarse and fine biomass decay. LANDIS-II simulates individual tree species with discrete lifehistory attributes, reproduction, and growth. Individual trees are not simulated; rather they are lumped into species and age bins or 'cohorts'.

Species can establish if the probability of dispersal to a site, which declines exponentially with distance to source sites, exceeds a random number (uniform distribution; 0 to 1) (Ward et al. 2005). Dispersal has a 'fat-tailed' distribution, whereby $95 \%$ of the probability is assigned to an effective distance and $5 \%$ is assigned to a maximum distance (Clark et al. 1998, Higgins et al. 2003b) (Table 1). The presence of mature cohorts within a cell enables that cell to serve as a seed source. The probability of dispersal into a cell increases as the number of source cells (those containing mature cohorts within the species' maximum dispersal distance) increases. In addition, the available light at a site must meet a species' light requirements, and the probability of establishment must exceed a random number (uniform distribution; 0 to 1$)$. The probability of establishment $\left(P_{\mathrm{EST}}\right)$ encapsulates the probability of seedling survival and is a function of soils and climate.

Each cohort has an associated aboveground biomass that is determined by the species' maximum aboveground net primary productivity (ANPP) in each ecoregion, cohort age, and inter- and intra-specific competition (Scheller \& Mladenoff 2004). Competition reduces actual ANPP when canopy-dominant cohorts suppress younger cohorts and faster-growing species out-compete slower-growing species (Scheller \& Mladenoff 2004).

\subsection{LANDIS-II configuration and parameterization}

For our simulations, cell resolution was $200 \times 200 \mathrm{~m}$ (4 ha) for a total of 212337 active cells. All processes were simulated at $10 \mathrm{yr}$ time steps. The study area was divided into 10 ecoregions (Host et al. 1996) within which we assumed that growth rates, decay rates, and establishment were constant during each $10 \mathrm{yr}$ period. The initial forest communities were generated from a satellite classification combined with forest inventory data (He et al. 1998).

ANPP was calculated using PnET-II (Aber \& Federer 1992) as described by Scheller \& Mladenoff (2004, 2005) for each species and ecoregion combination and for each climatic period. Actual ANPP is a function of age and competition among cohorts (Scheller \& Mladenoff 2004). We estimated the probability that a new cohort can establish $\left(P_{\mathrm{EST}}\right)$ using multiple simulations of the LINKAGES gap model (Pastor \& Post 1986, Scheller et al. 2005). $P_{\mathrm{EST}}$ is therefore limited by a climatic envelope defined by the minimum and maximum growing degree-days (Botkin et al. 1973, Nitschke \& Innes 2008), minimum January temperature, and moisture availability (Pastor \& Post 1986) for each species.

\subsection{Climate change and disturbance scenarios}

We simulated forest change over 200 yr beginning from 1990. Climate parameters were derived from 2 global circulation models (GCM): the second generation Hadley Centre for Climate GCM (HadCM2) and the first generation Canadian Climate Center GCM (CGCM1). Both models were based on the Intergovernmental Panel on Climate Change (IPCC) carbon emission scenario IS92A $\left(1 \% \mathrm{yr}^{-1}\right.$ compounded increase in equivalent $\mathrm{CO}_{2}$ plus sulfate aerosols) and predicted climate over the next 100 yr (IPCC 2007) (Fig. 2). After 2100, climate was held constant based on the final $10 \mathrm{yr}$ average of the respective climate models. In addition to the 2 climate change scenarios, a control scenario using $30 \mathrm{yr}$ (1961 to 1991) averages was simulated (Scheller \& Mladenoff 2005).

We also simulated 2 disturbance regimes for a total of 6 climate and disturbance combinations (Table 2). The first disturbance regime was a 'no disturbance' simulation, whereby only age-related tree mortality occurs. Second, we simulated a combination of wind and harvesting. The wind regime was estimated from 

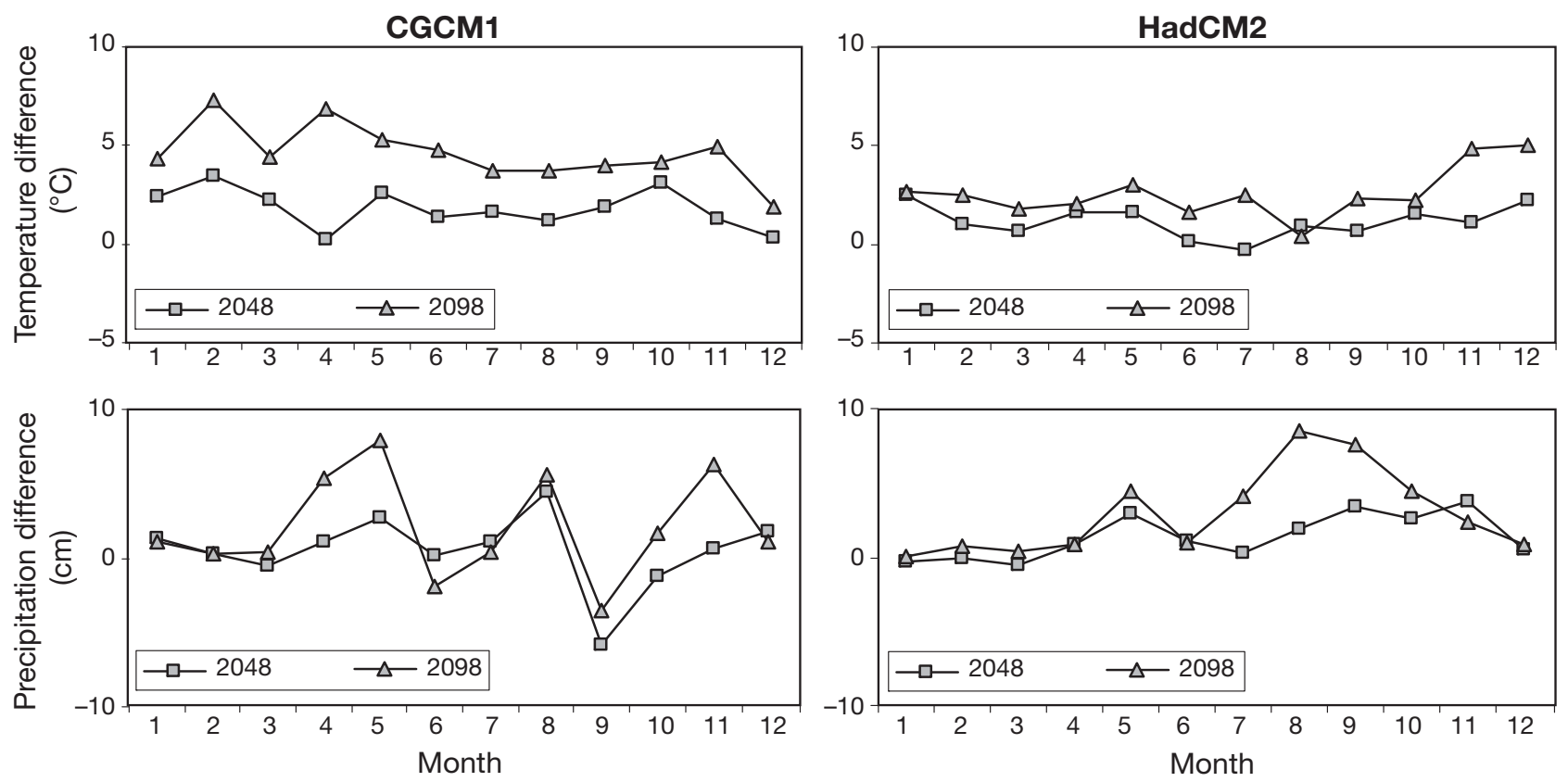

Fig. 2. Differences in mean monthly temperatures and precipitation between 2 climate change projections and the present day. Current climate is calculated from the $30 \mathrm{yr}$ (1960 to 1990) averages (ZedX 1995). HadCM2 and CGCM1 global circulation model projections are available from the VEMAP program (VEMAP Members 1995)

the historic record (Scheller \& Mladenoff 2005). The harvesting regime was designed to mimic current harvesting practices. Each harvesting prescription was sensitive to the species and age of harvested stands; therefore, harvest regimes changed over time as species composition changed (Gustafson et al. 2000, Scheller \& Mladenoff 2005).

\subsection{Data analyses}

We divided the study area into blocks for analysis. To avoid drawing conclusions from a single scale of analysis, we used 3 scales: $5 \times 5 \mathrm{~km}, 10 \times 10 \mathrm{~km}$, and $15 \times$

Table 2. Scenarios of climate change, disturbance, and seeding simulated; combined 12 total scenarios

\section{Disturbance scenarios}

No disturbance

Approximate current wind regimes and harvesting intensity

\section{Climate scenarios}

Hadley Centre for Climate Predictions (v2); IPCC IS92A

Canadian Climate Center (v1); IPCC IS92A

Current climate (ZedX 1995; average from 1961 to 1991)

\section{Migration scenarios}

Migration and range expansion are limited by dispersal (distance to seed source)

Migration and range expansion are not limited by dispersal (all seeds universally available)
$15 \mathrm{~km}\left(25,100\right.$, and $225 \mathrm{~km}^{2}$, respectively). The smallest area was dictated by our concern that each block contained an adequate sample size ( $\mathrm{n}=25$ cells) for calculating spatial statistics; the remaining scales were chosen to span an order of magnitude of area. We considered block sizes above $15 \times 15 \mathrm{~km}$ to be too coarse. Within each block, dependent and independent variables were calculated (see below). All calculations excluded non-forested sites.

\subsection{Dependent variables}

First, we evaluated the total reduction of aboveground live biomass due to limited species migration and range expansion ( $B_{\mathrm{LTD}}$ ) (Fig. 3 ; adapted from Scheller \& Mladenoff 2005). $B_{\text {LTD }}$ was estimated by duplicating each of the 6 principle scenarios ( 3 climate $\times 2$ disturbance) and removing dispersal limitations, i.e. propagules were available for every species at every site (Table 2).

Aboveground live biomass $\left(B_{\mathrm{AL}}\right)$ from scenarios with dispersal limitations were subtracted from the scenarios without dispersal limitations to calculate the effect of dispersal $\left(B_{\mathrm{DE}}\right)$ :

$$
\begin{aligned}
& B_{\mathrm{DE}}=B_{\mathrm{AL}} \text { (unlimited dispersal) } \\
& -B_{\mathrm{AL}} \text { (distance-limited dispersal) }
\end{aligned}
$$

To correct for the greater number of establishments when dispersal was unlimited, $B_{\mathrm{DE}}$ from the 2 control 


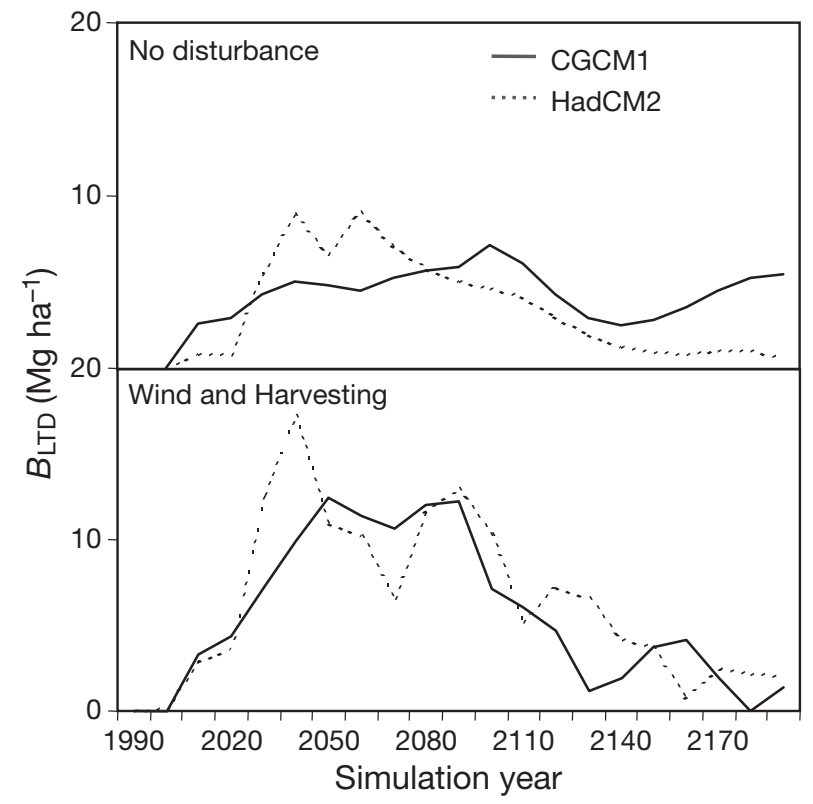

Fig. 3. Reduction of aboveground live biomass due to seed dispersal ( $\left.B_{\mathrm{LTD}}\right)$ according to global circulations models (GCM) for 2 climate scenarios (HadCM2 and CGCM1) and 2 disturbance scenarios (no disturbance, wind and harvesting combined)

climate scenarios (current climate $\times 2$ disturbance) were subtracted from each of the corresponding 4 climate change scenarios $(2$ climate change $\times 2$ disturbance). Using the CGCM1 with disturbance (CGCM1disturbed) as an example:

$$
\begin{aligned}
B_{\mathrm{LTD} \text { (CGCM1-disturbed) }}= & B_{\mathrm{DE}} \text { (CGCM1-disturbed) } \\
& -B_{\mathrm{DE} \text { (current climate disturbed) }}
\end{aligned}
$$

We averaged $B_{\text {LTD }}$ for the period from 2040 to 2100 , the period during which the combined effects of climate change and range expansion limitations were greatest. Prior to 2030, there is little change in climate. After 2100, climate is held constant and $B_{\text {LTD }}$ declines (Fig. 3).

Second, we examined the migration and range expansion of 2 southern tree species, bitternut hickory and white oak (maximum dispersal distances $3 \mathrm{~km}$ ), and a climate-neutral species, eastern hemlock (maximum dispersal distance $200 \mathrm{~m}$ ), using the change in their biomass from the year 1990 to the year $2190\left(B_{\mathrm{RE}}\right.$ biomass gained from species range expansion). Note that $B_{\mathrm{RE}}$ would be expected to respond in the opposite direction to $B_{\mathrm{LTD}}$ as it is a measure of biomass gain from migration. From our earlier analysis, we knew that these 3 species made a large contribution to total $B_{\text {LTD }}$ (Scheller \& Mladenoff 2005). We analyzed those blocks where each species was respectively present at the end of each of the 4 climate change and disturbance scenarios. Results from our $B_{\mathrm{LTD}}$ analysis did not indicate differences among scales, and we considered only the scale with the highest spatial resolution $\left(25 \mathrm{~km}^{2}\right)$ when analyzing $B_{\mathrm{RE}}$, allowing better detection of fragmentation and migration interactions. After an examination of residuals, $B_{\mathrm{RE}}$ was $\log$ transformed.

\subsection{Independent variables}

Forest fragmentation was estimated with 3 landscape metrics using the Image Analysis (IAN) spatial analysis program (DeZonia \& Mladenoff 2005). Initially, 7 class-level variables were calculated that we believed would be representative of the degree of fragmentation: aggregation index, area $\left(\mathrm{m}^{2}\right)$, mean polygon perimeter:area ratio (corrected), largest polygon index, number of polygons, average polygon area $\left(\mathrm{m}^{2}\right)$ (Fig. 4), and average polygon perimeter (m) (Gustafson 1998). Metrics were transformed if their distributions were not normal. These 7 metrics were highly correlated, and we selected the metric most highly correlated with all other metrics: the log of average polygon area (logAvPolyArea). The average polygon area also has the advantage of being relatively simple to interpret (when fragmentation is high, $\log$ AvPolyArea is low) and of being area weighted (Gustafson 1998).

The initial (year 1990) $B_{\mathrm{AL}}$ of each of the 22 tree species (Table 1) was calculated at each scale to estimate correlations between $B_{\mathrm{LTD}}$ or $B_{\mathrm{RE}}$ and the initial forest composition (the total initial $B_{\mathrm{AL}}$ is depicted in Fig. 4). Soil water holding capacity was included because it is a significant predictor of ANPP and tree species composition (Scheller \& Mladenoff 2005) and is visually congruent with the spatial variation in total $B_{\mathrm{AL}}$ (Fig. 4). Soil water holding capacity was calculated from STATSGO (1994) as described by Davidson \& Lefebvre (1993) (Fig. 4).

\subsection{Statistical analysis}

Our goal was to determine whether fragmentation and initial forest composition were correlated with the spatial distribution of $B_{\mathrm{LTD}}$ and $B_{\mathrm{RE}}$. Therefore, we did not attempt to maximize model adjusted- $\mathrm{R}^{2}$, and we regressed $B_{\mathrm{LTD}}$ and $B_{\mathrm{RE}}$ against all independent variables together to see how each variable performed holding all other variables constant (SAS Institute 2000). Initially, all variables were retained in order to substantiate a causal interpretation of the partial regression coefficients. Inclusion of all independent variables acknowledges that non-significant variables may still contribute to overall model structure. Variables with high multi-collinearity were identified using the variable inflation factor (VIF) (SAS Institute 2000), 

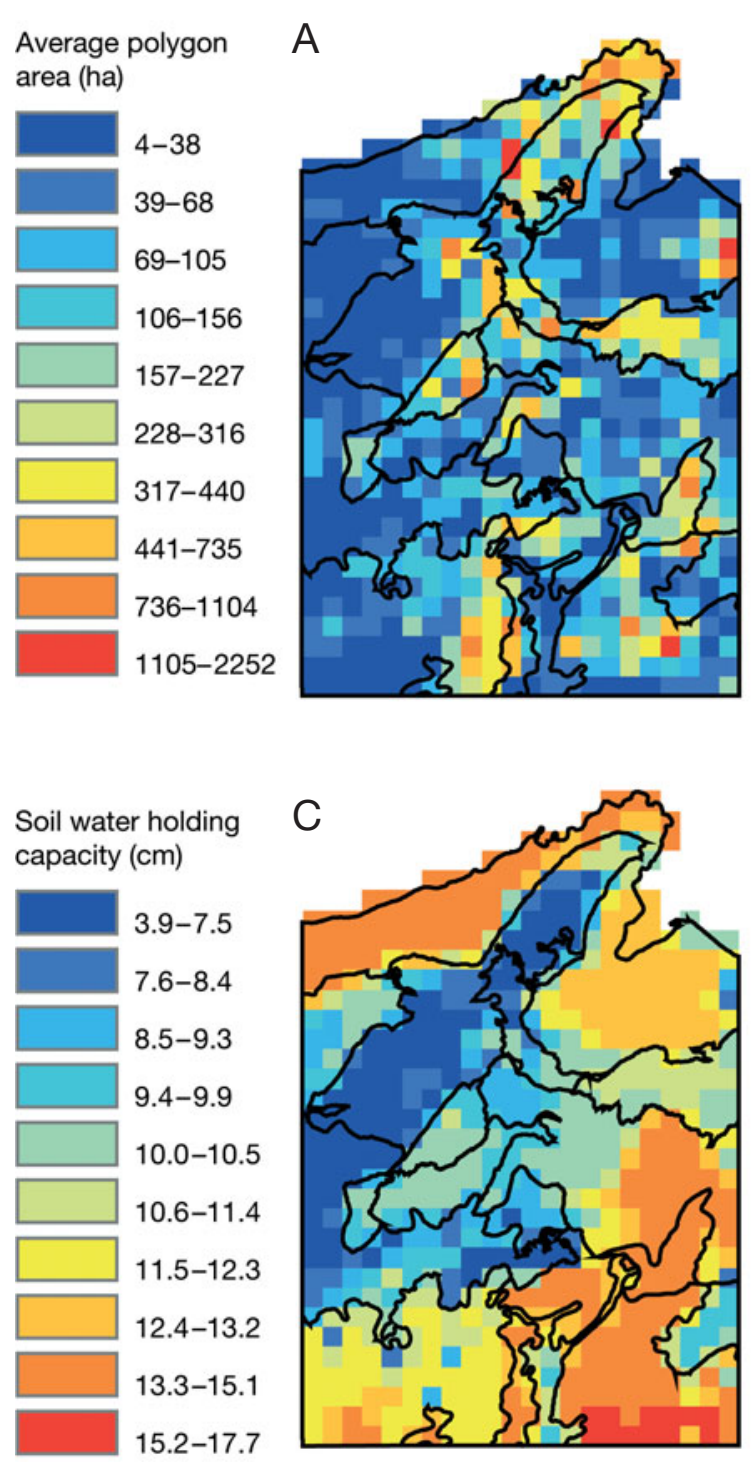

and we sequentially removed variables with a VIF $>10$ (SAS Institute 2000). We also included binary variables representing disturbance, climate, and a disturbance $\times$ climate interaction term. For each regression, residuals were inspected for spatial autocorrelation; we found no significant spatial autocorrelation for any of the 6 regressions ( $B_{\mathrm{LTD}}$ at 3 scales plus $B_{\mathrm{RE}}$ for 3 species).

\section{RESULTS}

\subsection{Total reduction in potential biomass}

For $B_{\mathrm{LTD}}$, the differences among the 3 scales of analyses did not show any changes in the sign of the correlations. With the exception of logAvPolyArea, statistical significance declines as the resolution decreases and sample size declines (Table 3 ). $B_{\text {LTD }}$ was significantly
Initial biomass $\left(\mathrm{Mg} \mathrm{ha}^{-1}\right)$
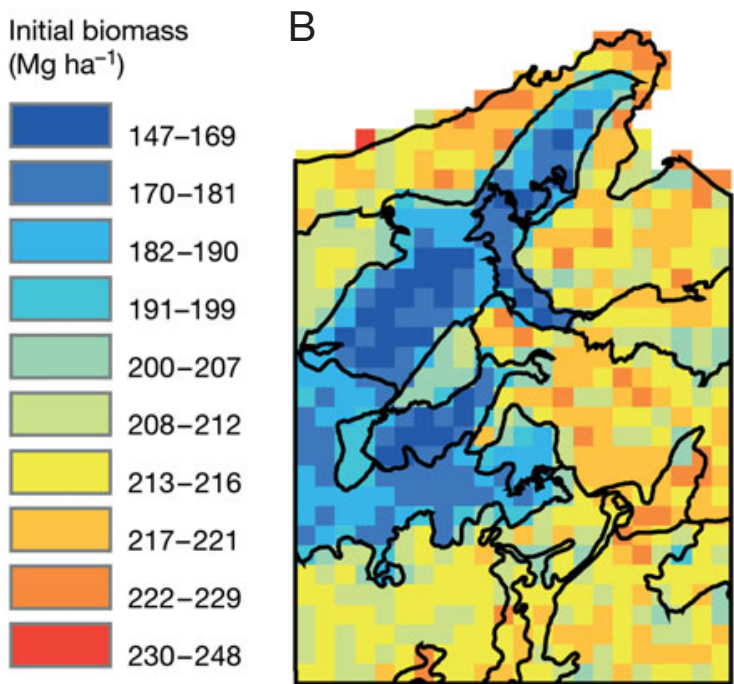

Fig. 4. (A) Mean polygon area (ha), (B) initial aboveground biomass $\left(\mathrm{Mg} \mathrm{ha}^{-1}\right)$, and $(\mathrm{C})$ soil water holding capacity $(\mathrm{cm})$ estimated for the year 1990, depicted at $5 \times 5 \mathrm{~km}$ resolution, for the study area in northwestern Wisconsin, USA. (-) Ecoregion boundaries

correlated with disturbance regime (wind and harvesting versus no disturbance), but not climate change projection (HadCM2 or CGCM1) nor the disturbance $\times$ climate change interaction term. Water-holding capacity was not significantly correlated with $B_{\text {LTD }}$.

Our measure of landscape fragmentation, logAvPolyArea, was negatively correlated with $B_{\text {LTD }}$ (Table 3 ), indicating that as mean forested patch size declined, total dispersal declined and potential aboveground live biomass was reduced.

A positive correlation between the initial biomass for a particular species and $B_{\mathrm{LTD}}$ (Table 3 ) indicates that that species may have a significantly reduced ability to migrate and expand its range. Likewise, we inferred that species with an initial biomass negatively correlated with $B_{\text {LTD }}$ contributed significantly to total migration.

\subsection{Individual species range expansion}

Our fragmentation index (logAvPolyArea) was positively correlated with $B_{\mathrm{RE}}$ for white oak Quercus alba and eastern hemlock Tsuga canadensis, indicating that forest patch size was positively correlated with their ability to colonize new areas (Table 3 ). $B_{\mathrm{RE}}$ for bitternut hickory Carya cordiformis (Fig. 5) was correlated with disturbance regime, climate projection, and the disturbance $\times$ climate interaction (Table 3 ). White oak migration was correlated with disturbance and climate, 
Table 3. The 26 variables regressed against total $B_{\mathrm{LTD}}$ (the reduction in aboveground live biomass due to range expansion limitations) and total $B_{\mathrm{RE}}$ (the increase in aboveground live biomass due to species range expansion) for the period from 2040 to 2100 . Coefficient signs indicating a positive or negative correlation are given where $\mathrm{p}$ is significant. Categorical variables (disturbance, climate change project, or the disturbance $\times$ climate interaction) were not given signs (na: not applicable). ns: non-significant variables with p > 0.10; NI: a variable removed from the analysis due to a high multi-collinearity as indicated by a high variance inflation factor

\begin{tabular}{|c|c|c|c|c|c|c|c|c|c|c|c|c|}
\hline \multirow[b]{2}{*}{ Parameter } & \multicolumn{2}{|c|}{$\begin{array}{l}\text { Scale }= \\
5 \times 5 \mathrm{~km}\end{array}$} & \multicolumn{2}{|c|}{$\begin{array}{c}B_{\mathrm{LTD}} \\
\text { Scale }= \\
10 \times 10 \mathrm{~km}\end{array}$} & \multicolumn{2}{|c|}{$\begin{array}{c}\text { Scale = } \\
15 \times 15 \mathrm{~km}\end{array}$} & \multicolumn{2}{|c|}{$\begin{array}{c}\text { C. } \\
\text { cordiformis }\end{array}$} & \multicolumn{2}{|c|}{$\begin{array}{c}-B_{\mathrm{RE}} \\
Q . \\
\text { alba }\end{array}$} & \multicolumn{2}{|c|}{$\begin{array}{c}T . \\
\text { canadensis }\end{array}$} \\
\hline & Sign & $\mathrm{p}$ & Sign & $\mathrm{p}$ & Sign & $\mathrm{p}$ & Sign & $\mathrm{p}$ & Sign & $\mathrm{p}$ & Sign & $\mathrm{p}$ \\
\hline Intercept & & 0.0001 & & ns & & ns & + & 0.0344 & - & 0.0001 & - & 0.0001 \\
\hline \multicolumn{13}{|l|}{ Categorical variables } \\
\hline Disturbance & na & 0.0001 & na & 0.0001 & na & 0.0001 & na & 0.0001 & na & 0.0001 & na & 0.0001 \\
\hline Climate change projection & & ns & & ns & & ns & na & 0.0001 & na & 0.0638 & na & 0.0596 \\
\hline $\begin{array}{l}\text { Disturbance } \times \\
\text { climate change projection }\end{array}$ & & ns & & ns & & ns & na & 0.0001 & & ns & & ns \\
\hline \multicolumn{13}{|l|}{ Continuous variables } \\
\hline \multicolumn{13}{|l|}{ Fragmentation and soils } \\
\hline logAvPolyArea & - & 0.0003 & & ns & - & 0.0286 & + & 0.0185 & & ns & + & 0.0058 \\
\hline $\begin{array}{l}\text { Soil water holding } \\
\text { capacity }(\mathrm{cm})\end{array}$ & & ns & & ns & & ns & - & 0.0005 & + & 0.0553 & + & 0.0001 \\
\hline \multicolumn{13}{|l|}{ Northern species } \\
\hline Abies balsamea & + & 0.0001 & + & 0.0001 & + & 0.0023 & & ns & & ns & + & 0.0628 \\
\hline Betula papyrifera & - & 0.0001 & - & 0.0002 & - & 0.0109 & & $\mathrm{~ns}$ & + & 0.0001 & + & 0.0050 \\
\hline Picea glauca & - & 0.0001 & - & 0.0001 & - & 0.0168 & & $\mathrm{~ns}$ & + & 0.0368 & + & 0.0001 \\
\hline Pinus banksiana & + & 0.0001 & + & 0.0001 & + & 0.0007 & - & 0.0001 & - & 0.0566 & & $\mathrm{~ns}$ \\
\hline Pinus resinosa & & ns & & ns & & $\mathrm{ns}$ & + & 0.0076 & + & 0.0015 & - & 0.0906 \\
\hline Thuja occidentalis & - & 0.0016 & & ns & - & 0.0622 & + & 0.0004 & + & 0.0863 & + & 0.0001 \\
\hline \multicolumn{13}{|l|}{ Climate-neutral species } \\
\hline Acer saccharum & & NI & & NI & & NI & & NI & & NI & & NI \\
\hline Betula alleghaniensis & - & 0.0001 & - & 0.0001 & - & 0.0472 & & NI & & $\mathrm{ns}$ & + & 0.0001 \\
\hline Pinus strobus & & ns & & ns & & ns & & ns & - & 0.0151 & + & 0.0011 \\
\hline Populus grandidentata & + & 0.0001 & & ns & & ns & + & 0.0080 & + & 0.0017 & & ns \\
\hline Populus tremuloides & + & 0.0001 & + & 0.0357 & & ns & - & 0.0026 & & ns & + & 0.0006 \\
\hline Quercus ellipsoidalis & & ns & & ns & & ns & & ns & & ns & & ns \\
\hline Quercus macrocarpa & & ns & & ns & & $\mathrm{ns}$ & + & 0.0566 & - & 0.0914 & & $\mathrm{~ns}$ \\
\hline Quercus rubra & - & 0.0001 & - & 0.0103 & & ns & & NI & & ns & + & 0.0708 \\
\hline Tilia americana & & NI & & NI & & NI & & NI & - & 0.0170 & - & 0.0278 \\
\hline Tsuga canadensis & + & 0.0133 & & ns & & ns & & ns & & ns & + & 0.0001 \\
\hline \multicolumn{13}{|l|}{ Southern species } \\
\hline Acer rubrum & & ns & & ns & & ns & - & 0.0001 & + & 0.0329 & + & 0.0004 \\
\hline Carya cordiformis & & ns & & ns & & $\mathrm{ns}$ & & $\mathrm{ns}$ & & ns & + & 0.0001 \\
\hline Fraxinus americana & - & 0.0002 & - & 0.0034 & & ns & & NI & & NI & + & 0.0001 \\
\hline Prunus serotina & - & 0.0001 & - & 0.0008 & & ns & - & 0.0008 & - & 0.0582 & - & 0.0539 \\
\hline Quercus alba & & ns & & ns & & ns & & ns & + & 0.0001 & + & 0.0001 \\
\hline
\end{tabular}

although not the disturbance $\times$ climate interaction. Hemlock range expansion was not correlated with either disturbance or climate change projection.

We tallied the ratio of negative correlations (high competitive exclusion) to positive correlations (low or no competitive exclusion) between $B_{\mathrm{RE}}$ and initial $B_{\mathrm{AL}}$ for all 22 species. Of the significant correlations between the initial $B_{\mathrm{AL}}$ of northern tree species and $B_{\mathrm{RE}}$ for the 3 species examined in detail, 3 were negative and 10 were positive (ratio $=0.30$ ). These ratios suggest that inter-specific competition was lowest within areas initially dominated by the northern species. For climate-neutral species (species neither near the northern nor southern edges of their distribution), 5 of the interactions with $B_{\mathrm{RE}}$ were negative, 7 were positive (ratio $=0.71$, excluding the positive interaction between hemlock $B_{\mathrm{RE}}$ and initial hemlock abundance). For southern species, 4 of the interactions with $B_{\mathrm{RE}}$ were negative, 5 were positive (ratio $=0.8$, excluding the positive interaction between white oak $B_{\mathrm{RE}}$ and initial white oak abundance) (Table 3).

The maps of $B_{\mathrm{RE}}$ for our 3 species (Fig. 5) indicate that bitternut hickory and white oak had the largest increase of $B_{\mathrm{AL}}$ in scenarios with disturbance, while hemlock had the largest increase in no-disturbance scenarios. The $B_{\mathrm{RE}}$ maps also reflect initial distributions, whereby hemlock had the broadest initial distribution and bitternut hickory the smallest (Fig. 5). 

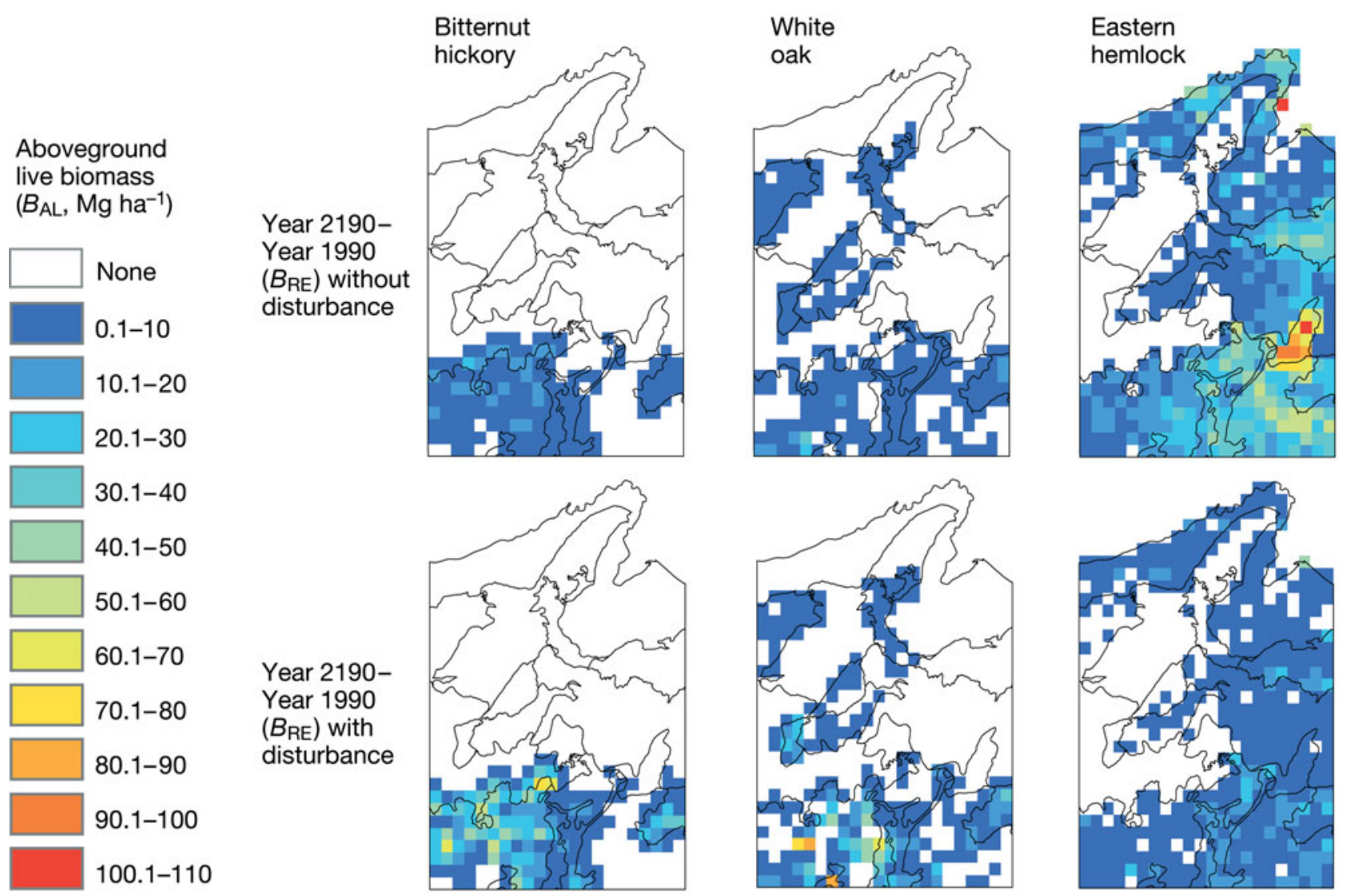

Fig. 5. Carya cordiformis, Quercus alba, Tsuga canadensis. The effect of limitation to species range expansion on aboveground live biomass $\left(B_{\mathrm{RE}}\right)$ of 3 tree species in northwestern Wisconsin, USA, under the CGCM1 climate forecast. Scenarios without disturbance and with wind and harvesting combined are depicted. Resolution is $5 \times 5 \mathrm{~km}$; white areas indicate species absence.

\section{(一) Ecoregion boundaries}

\section{DISCUSSION}

Our simulations bring together many complex interactions among climate change, fragmentation, dispersal, and competition. The results demonstrate the complex interactions that may cause a lag in tree species response to rapid climate change and diminish potential aboveground live biomass. Our results indicate that forest ecosystem responses to climate change will be highly species dependent and a function of human alterations to the landscape, competitive interactions, and disturbance.

Regardless of the many process interactions simulated, fragmentation had a negative effect on total species migration and the range expansion of the 3 individual species examined. These results support prior research that has measured (Hewitt \& Kellman 2002) or simulated (Malanson \& Cairns 1997, Collingham \& Huntley 2000, Higgins et al. 2003b, Iverson et al. 2004b) the negative effects of fragmentation on tree species dispersal.

The role of competition in reducing migration or range expansion was also supported by our simula- tions. We posited that a positive correlation between $B_{\mathrm{LTD}}$ and the climate-neutral species would be indicative of competitive exclusion of the more southern species. Only 3 species, big-toothed aspen Populus grandidentata, trembling aspen $P$. tremuloides, and eastern hemlock Tsuga canadensis demonstrated such a correlation. When harvested, aspen readily regenerates vegetatively and quickly dominates the canopy, which would exclude other shade-intolerant species from seeding into these sites. Hemlock casts deep shade, is long-lived, and is currently under-dispersed relative to its historic range (Crow 1978). Previous simulations indicated robust growth and establishment of hemlock in this landscape if climate warms and precipitation is adequate (Scheller \& Mladenoff 2005). Therefore, hemlock would also be expected to reduce the dispersal of less shade-tolerant southern species. We would expect a similar limitation to be caused by sugar maple Acer saccharum, although it was not included in the final statistical model (Table 3). Together, sites currently dominated by aspen, hemlock, or sugar maple may create competitive migration barriers for southern species. However, where the initial $B_{\mathrm{AL}}$ of southern 
species was significantly correlated to $B_{\mathrm{LTD}}$, the correlation was negative. This implies that where more southerly species (Table 1) already exist, they contributed significantly to total migration, and $B_{\mathrm{AL}}$ was not limited by the absence of climate-adapted species.

Two climate-neutral species, yellow birch Betula alleghaniensis and red oak Quercus rubrum, were negatively correlated with $B_{\mathrm{LTD}}$. Although facilitation is possible, it is more likely that these mid-shade-tolerant species did not impede total migration. Various northern species were either positively or negatively correlated with $B_{\mathrm{LTD}}$. All of these species (except eastern white cedar Thuja occidentalis) were estimated to be extirpated if climate warms as predicted (Scheller \& Mladenoff 2005). Therefore, neither direct competition nor facilitation are likely. Rather, depending upon how quickly and where the northern species declined fastest, they would likely be replaced by either climate-neutral species (contributing to competitive exclusion) or southern species. A positive correlation between $B_{\text {LTD }}$ and the initial distribution of northern species indicates those northern species that declined faster than they were replaced.

Likewise, our individual examination of bitternut hickory Carya cordiformis, white oak Quercus alba, and eastern hemlock Tsuga canadensis also indicate where inter-specific competition may be strongest. Our ratios of significant competitive to non-competitive interactions suggest that inter-specific competition was lowest (the smallest ratio of negative to positive correlation; 0.30) within areas initially dominated by the northern species. Inter-specific competition was similar for areas initially dominated by climate-neutral or southern species (ratios of 0.71 and 0.8 , respectively). These results are consistent with our expectation that inter-specific competition would have the smallest effect on range expansion where northern tree species were extirpated, removing competitive barriers to migration and range expansion.

Although our simulations suggest that competition is not limiting where northern species currently dominate, these results reflect our use of a southern range limit dictated by a maximum number of growing degree days (GDD). The germination probability of many northern tree species is limited by high temperatures (Farmer 1997), and a chilling period may be required for budburst (Sykes et al. 1996, Walker et al. 2002); therefore, it is unlikely that the southern range limit of all tree species is determined by competition alone, contrary to Loehle (1998). Nevertheless, the use of maximum GDD as a component of species' bioclimatic envelopes is conservative (Sykes et al. 1996, Loehle 2000a), and areas currently dominated by northern species may remain so for a longer period than we estimated. In which case, these species could serve as additional competitive barriers to migration. Competition as a longer term, migration-related limitation to northern range boundaries is complementary to the expectation that growth trade-offs and competition help define the southern range limits for many species (Loehle 1998). These results extend the competitive effects as simulated by Malanson \& Cairns (1997) by simulating competitive growth among extant tree species across a large landscape.

Historically, hemlock was much more widely dispersed and abundant in this region (Schulte et al. 2002), and our results (Fig. 5) imply that a broad reinvasion of previously available habitat is possible (Scheller \& Mladenoff 2005). However, the projected expansion of hemlock may be overestimated due to processes that were not simulated, principally deer browsing (Mladenoff \& Stearns 1993) and the possible expansion of the hemlock wooly adelgid, Adelges tsugae, distribution under climate change (Dale et al. 2001).

Our simulated migrations of bitternut hickory and white oak infer that migration may be geographically limited for many species whose range is expected to shift northwards (Fig. 5). Migration distances for bitternut hickory and white oak were typically $<10 \mathrm{~km}$ over the $200 \mathrm{yr}$ simulation $\left(<50 \mathrm{~m} \mathrm{yr}^{-1}\right.$; data not shown), although both had a maximum dispersal distance of $3 \mathrm{~km}$. These migration rates are below the range estimated from simulations (100 to $200 \mathrm{~m} \mathrm{yr}^{-1}$ ) (Iverson et al. 2004b) and closer to estimates from molecular studies (80 to $90 \mathrm{~m} \mathrm{yr}^{-1}$ ) (Mclachlan et al. 2005). In effect, our realized migration rates were always less than the potential (Higgins et al. 2003b). Although these species occasionally became established $>2 \mathrm{~km}$ from the nearest seed source, subsequent range expansion was limited by fragmentation and competition. Similarly, Iverson et al. (2004b) found that occasional long-distance dispersal events did not drive overall migration rates.

Our results are a function of the complex interactions simulated, including competition, dispersal, harvesting, and climate change, and it is difficult to assign causality to any particular correlative result. Furthermore, there is considerable uncertainty about the historic and current rates of tree species migration rates (Clark 1998, Higgins et al. 2003a, Mclachlan et al. 2005) and the expected rate and magnitude of climate change (IPCC 2007). We did not simulate all of the processes that will potentially alter forest composition and biomass, including herbivores, land-use change, or the potential for human-enhanced long-distance dispersal or plantings (Iverson et al. 2004a). Both $P_{\text {EST }}$ and ANPP may be sensitive to $\mathrm{CO}_{2}$ fertilization ( $\mathrm{Xu}$ et al. 2007), although this potential effect was not included in the current analysis. Of particular relevance to species 
migration or range expansion, there is a need for greater attention to mechanisms of seed dispersal, including directional seed dispersal and stochastic masting events. Finally, projections of the future cannot be validated (Rastetter 1996). For all these reasons, our results should never be interpreted as predictions. Rather, each scenario should be regarded as a tightly controlled experiment and is only relevant in the context of comparison to the other scenarios generated.

\section{CONCLUSIONS}

Our simulations of the effects of fragmentation and competition in the context of a larger landscape and the regular occurrence of the most prevalent disturbances improve upon our understanding of the interactions among climate change, biotic interactions, and human alterations of the landscape. Our results are consistent with our expectations that forest fragmentation would reduce total dispersal and, subsequently, reduce potential aboveground live biomass. Given global land-use patterns, we can expect these consequences to be widespread and, on average, to increase in magnitude over time. Our results also indicate that inter-specific competition may further reduce species migration and range expansion where there is the potential for existing species to reduce the growth or establishment of species expected to migrate northward (Davis 1989, Malanson \& Cairns 1997, Loehle 1998). Although higher temperatures in tandem with increased precipitation may cause a net increase in aboveground carbon storage, these positive effects will be tempered by dispersal barriers as demonstrated and accompanied by a decline in species richness (Scheller \& Mladenoff 2005).

Acknowlegement. This research was supported by the US Forest Service North Central Research Station. Dr Hong He provided the original landscape classification. Two anonymous reviewers provided excellent and critical feedback on our manuscript.

\section{LITERATURE CITED}

Aber JD, Federer CA (1992) A generalized, lumped-parameter model of photosynthesis, evapotranspiration and net primary production in temperate and boreal forest ecosystems. Oecologia 92:463-474

Botkin DB, Janak JF, Wallis JR (1973) Some ecological consequences of a computer model of forest growth. J Ecol 60:849-872

- Clark JS (1998) Why trees migrate so fast: confronting theory with dispersal biology and the paleorecord. Am Nat 152: 204-224

Clark JS, Fastie C, Hurtt G, Jackson ST and others (1998) Reid's paradox of rapid plant migration. Bioscience 48: 13-24
Collingham YC, Huntley B (2000) Impacts of habitat fragmentation and patch size upon migration rates. Ecol Appl 10:131-144

Crow TR (1978) Biomass and production in three contiguous forests in northern Wisconsin. Ecology 59:265-273

Currie DJ (2001) Projected effects of climate change on patterns of vertebrate and tree species richness in the conterminous United States. Ecosystems (NY, Print) 4:216-225

Curtis JT (1959) The vegetation of Wisconsin. An ordination of plant communities. The University of Wisconsin Press, Madison, WI

> Dale VH, Joyce LA, Mcnulty S, Neilson RP and others (2001) Climate change and forest disturbances. Bioscience 51: 723-734

> Davidson EA, Lefebvre PA (1993) Estimating regional carbon stocks and spatially covarying edaphic factors using soil maps at three scales. Biogeochemistry 22:107-131

Davis MB (1989) Lags in vegetation response to greenhouse warming. Clim Change 15:75-82

DeZonia B, Mladenoff DJ (2005) IAN 1.0.7. Available at http://landscape.forest.wisc.edu/projects/ian/

Farmer RE Jr (1997) Seed ecophysiology of temperate and boreal zone forest trees. St. Lucie Press, Delray Beach, FL

Gustafson EJ (1998) Quantifying landscape spatial pattern: What is the state of the art? Ecosystems 1:143-156

Gustafson EJ, Shifley SR, Mladenoff DJ, Nimerfro KK, He HS (2000) Spatial simulation of forest succession and timber harvesting using LANDIS. Can J For Res 30:32-43

> He HS, Mladenoff DJ, Radeloff VC, Crow TR (1998) Integration of GIS data and classified satellite imagery for regional forest assessment. Ecol Appl 8:1072-1083

> Hewitt N, Kellman M (2002) Tree seed dispersal among forest fragments. II. Dispersal abilities and biogeographical controls. J Biogeogr 29:351-363

- Higgins SI, Clark JS, Nathan R, Hovestadt T and others (2003a) Forecasting plant migration rates: managing uncertainty for risk assessment. J Ecol 91:341-347

Higgins SI, Lavorel S, Revilla E (2003b) Estimating plant migration rates under habitat loss and fragmentation. Oikos 101:354-366

> Host GE, Polzer PL, Mladenoff DJ, White MA, Crow TR (1996) A quantitative approach to developing regional ecosystem classifications. Ecol Appl 6:608-618

IPCC (Intergovernmental Panel on Climate Change) (2007) Climate change 2007: the scientific basis. Cambridge University Press, Cambridge

Iverson LR, Prasad AM (2001) Potential changes in tree species richness and forest community types following climate change. Ecosystems (NY, Print) 4:186-199

> Iverson LR, Prasad A, Schwartz MW (1999) Modeling potential future individual tree-species distributions in the eastern United States under a climate change scenario: a case study with Pinus virginiana. Ecol Model 115:77-93

> Iverson LR, Schwartz MW, Prasad AM (2004a) Potential colonization of new available tree-species habitat under climate change: an analysis of five eastern US species. Landscape Ecol 19:787-799

Iverson LR, Schwartz MW, Prasad AM (2004b) How fast and far might tree species migrate in the eastern United States due to climate change? Glob Ecol Biogeogr 13:209-219

> Loehle C (1998) Height growth rate tradeoffs determine northern and southern range limits for trees. J Biogeogr 25:735-742

> Loehle C (2000a) Forest ecotone response to climate change: sensitivity to temperature response functional forms. Can J For Res 30:1632-1645

Loehle C (2000b) Strategy space and the disturbance spec- 
trum: a life-history model for tree species coexistence. Am Nat 156:14-33

Loehle C, LeBlanc D (1996) Model-based assessments of climate change effects on forests: a critical review. Ecol Model 90:1-31

Malanson GP, Cairns DM (1997) Effects of dispersal, population delays, and forest fragmentation on tree migration rates. Plant Ecol 131:67-79

Malcolm JR, Markham A, Neilson RP, Garaci M (2002) Estimated migration rates under scenarios of global climate change. J Biogeogr 29:835-849

Mclachlan JS, Clark JS, Manos PS (2005) Molecular indicators of tree migration capacity under rapid climate change. Ecology 86:2088-2098

Mladenoff DJ (2004) LANDIS and forest landscape models. Ecol Model 180:7-19

Mladenoff DJ, Stearns F (1993) Eastern hemlock regeneration and deer browsing in the northern Great Lakes region: a re-examination and model simulation. Conserv Biol 7: 889-900

Nitschke CR, Innes JL (2008) A tree and climate assessment tool for modelling ecosystem response to climate change. Ecol Model 210:263-277

Pastor J, Post WM (1986) Development of a linked forest productivity-soil process model, Vol 86. Oak Ridge National Laboratory Oak Ridge, TN

Rastetter EB (1996) Validating models of ecosystem response to climate change. Bioscience 46:190-198

SAS Institute (2000) SAS online doc, Version 8. SAS Institute, Cary, NC

Scheller RM, Mladenoff DJ (2004) A forest growth and biomass module for a landscape simulation model, LANDIS: design, validation, and application. Ecol Model 180:211-229

Scheller RM, Mladenoff DJ (2005) A spatially interactive simulation of climate change, harvesting, wind, and tree species migration and projected changes to forest composition and biomass in northern Wisconsin, USA. Glob Change Biol 11:307-321

Scheller RM, Mladenoff DJ, Crow TR, Sickley TS (2005) Sim-

Editorial responsibility: Nils Chr. Stenseth,

Oslo, Norway ulating the effects of fire reintroduction versus continued suppression on forest composition and landscape structure in the Boundary Waters Canoe Area, northern Minnesota (USA). Ecosystems (NY, Print) 8:396-411

> Scheller RM, Domingo JB, Sturtevant BR, Williams JS, Rudy A, Gustafson EJ, Mladenoff DJ (2007) Design, development, and application of LANDIS-II, a spatial landscape simulation model with flexible spatial and temporal resolution. Ecol Model 201:409-419

Schulte LA, Mladenoff DJ, Nordheim EV (2002) Quantitative classification of a historic northern Wisconsin (USA) landscape: mapping forests at regional scales. Can J For Res 32: $1616-1638$

STATSGO (State Soil Geographic) (1994) State soil geographic data base. Data use information, Vol 94. US Dept. of Agriculture National Cartography and GIS Center, Fort Worth, TX

Sykes MT, Prentice IC, Cramer W (1996) A bioclimatic envelope for the potential distribution of north European tree species under present and future climates. J Biogeogr 23: 203-233

VEMAP Members (1995) Vegetation/ecosystem modeling and analysis project: comparing biogeography and biogeochemistry models in a continental-scale study of terrestrial ecosystem responses to climate change and $\mathrm{CO}_{2}$ doubling. Global Biogeochem Cycles 9:407-437

Walker KV, Davis MB, Sugita S (2002) Climate change and shifts in potential tree species range limits in the Great Lakes region. J Gt Lakes Res 28:555-567

Ward BC, Mladenoff DJ, Scheller RM (2005) Landscape-level effects of the interaction between residential development and public forest management in northern Wisconsin, USA. For Sci 51:616-632

Xu C, Gertner GZ, Scheller RM (2007) Potential effects of interaction between $\mathrm{CO}_{2}$ and temperature on Boundary Water Canoe Area's forest landscape response to global warming. Glob Change Biol 13:1469-1483

ZedX (1995) Hi-rez data climatological series. ZedX, Boalsburg, PA

Submitted: August 6, 2007; Accepted: April 7, 2008

Proofs received from author(s): June 2, 2008 